\title{
Effects of Accounting Information Quality, Accountability, and Transparency on Zakat Acceptance
}

\author{
${ }^{1}$ NIKMATUNIAYAH, ${ }^{2}$ MARLIYATI, ${ }^{3}$ LILIS MARDIANA A \\ ${ }^{12}$ Bidang Akuntansi, Jurusan Akuntansi, Politeknik Negeri Semarang, Jl Prof Soedharto SH Tembalang Semarang \\ ${ }^{3}$ Bidang Hukum Bisnis, Jurusan Akuntansi, Politeknik Negeri Semarang, Semarang \\ email: ${ }^{1}$ nikmatuniayah@rocketmail.com; ${ }^{2}$ marliyati@polines.ac.id; ${ }^{3}$ lilis_mardiana68@yahoo.co.id
}

\begin{abstract}
This study aims to prove the effects of accounting information quality, accountability, and transparency on the acceptance of zakat. The population of this research is Zakat Collection Agency (LAZ) in Semarang City, Central Java province. The samples are taken by using purposive sampling. They are Zakat Collection Agency in Semarang that have the largest zakat revenue source and the widest distribution. The research samples taken include: BAZNAS Semarang, LAZISBA Baiturrahman Masjid, DPU Daarut Tauhid (DT Public Works Services), Rumah Zakat, Pos Keadilan Peduli Ummah (PKPU), and Dompet Dhuafa. The data are collected on June - July 2016. The data are processed by using Multiple Regression method. The results show that the Quality of Accounting Information, Accountability, and Transparency affect the Level of Acceptance of Zakat Fund.
\end{abstract}

Keywords: quality of accounting information, accountability, transparency, zakat

\section{Introduction}

Zakat Collection Agency (Lembaga Amil Zakat or $L A Z$ ) is a non-profit organization that manages public funds derived from zakat, infaq and sodaqoh for the sake of ummah. LAZ receives zakat, infaq and sodaqoh from muzakki then distributes it in various activities such as educational aid, health, business capital, and so on to the economically weak communities. Since LAZ is entrusted by muzakki (people who pay zakat), it accounts for the zakat management to muzakki or community. The accountability of zakat management is in the form of a transparent and accountable financial statement.

Transparency of financial statement is financial statement presented openly, accurately and transparently. LAZ's financial statements become very strategic to increase the accountability and transparency to muzakki and especially to Allah SWT, as a result it will generate trust to the muzakki and community. In a previous study (Nikmatuniayah, 2015) it is found that the accountability of LAZ zakat financial statements is addressed to:
Community, State, Prophet Muhammad, and Allah.

The obligation to implement accountability by LAZ has been claimed under Law No. 38 of 1999 on zakat management. The enactment of Law No. 23 of 2011 on zakat management is questionable whether the growth of zakat committees is accompanied by a good management and accountability. In Article 19 of the Law, it is said that every Zakat Management Organization shall report the collection, distribution, and utilization of zakat that has been audited to Baznas on a regular basis (Bisri, Zaini 2012).

The government confirms that the requirement for LAZ is it must have good bookkeeping by presenting the financial statements. "For that financial statements to be accountable and transparent then it requires accounting standards governing it," (Istutik, 2013). Currently, the financial statements for zakat are set forth in the Statement of Financial Accounting Standard (PSAK) 109. The head of the ZIS amil committee must continuously provide written

Received: October 17, 2016, Revision: May 30, 2017, Accepted: May 19, 2017

Print ISSN: 0215-8175; Online ISSN: 2303-2499.

Accredited by DIKTI. SK Kemendikbud, No.040/P/2014, valid 18-02-2014 until 18-02-2019, Indexed by DOAJ 
accountability reports to the Supreme Advisory Council concerning the finance and operation within a period (Suroso, 2007).

In the previous study (Nikmatuniayah et.al., 2015b), it is found that only $70 \%$ of LAZ follow the Statement of Financial Accounting Standard (PSAK) 109 in presenting the financial statements. City BAZNAS (National Zakat Collection Agency) and all regional BAZ (Zakat Collection Agency) have not followed the Statement of Financial Accounting Standard (PSAK) 109. According to Wibisono (2011), accountability report (financial) of zakat committee in practice is not standardized since there is no standard, so if the zakat committees report the distribution of zakat, there are possibilities that they are considered not truly distributed it because it is treated as public interests. Research on the accountability of zakat financial statements, especially those containing accounting standard and zakat reporting are few in number. Therefore, it is necessary to study the accountability and transparency of LAZ financial statements on the acceptance of zakat.

\section{Accountability and Transparency of Financial Statements}

Accountability arises as a logical consequence of the relationship between the management (agent) and owner (principal), resulting in a dynamic relationship in the form of agent-principal relationship. Principal in this case gives full authority to the agent to perform the activities of organizational operation. As a consequence of this authority, the agent must account for its activities to the principal, Gray, Owen and Mounders $(1991 ; 6)$ define accountability as the onus requirement or responsibility to provide account (by no means necessarily a financial account) or reckoning of action of which one is held responsible. Here the principal in the context of zakat financial management is the trustee (muzakki) and God. This means that the management of the agent must be accountable for the use of resources to both parties above.

Accountability means a basic obligation for an agency to pay attention to the community or shareholder for their various activities and achievements. This principle ensures to the community that they have the opportunity to know who and how decisions are made and the underlying reasons. At the same time, the transparency principle refers to one's openness to community in order to get the right information and the confidentiality of the company as the working element. In this context, transparency becomes a community control on the zakat management organization so that transparency is associated with the access for community to get as much information as possible. Community should know a number of things, including: organizational charters, and internal and external control mechanisms. External audits should be conducted to encourage the transparency of zakat management organizations, something never be done before, so the accountability of modern organizations becomes clear (Herlina, 2004).

The following research Hermawan, Sigit \& Astriana, Gianti (2010), examines zakat accounting and transparency and accountability of LAZ. The conclusion of this research is the form of transparency and accountability of LAZNAS XYZ to the stakeholder of this agency reflected in the financial statements presented both through data received by the researcher or data that can be accessed directly on the official website. The limitations of this study also do not explain the accounting and reporting process of zakat conform to Statement of Financial Accounting Standards (PSAK 109).

The results of Huda, Nurul \& Sawarjuwono, Tjiptohadi's research (2013) shows the overlap of the Zakat Management Organization (Organisasi Pengelola Zakat) OPZ) partnership program, government policy contrary to the professional empowerment program. This research proposes an idea to increase the accountability of zakat i.e, mustahik and muzakki data compilation through mosque, preparation of amil officers in collaboration with universities, and the need of zakat distribution as national and interdepartmental program, cooperation with Training Need Assessment (Identifikasi Kebutuhan Diklat/IKD) and Mosque Welfare Councils DKM).

\section{Media Accountability of Financial Statements}

The accountability system for an adequate Zakat Collection Agency or LAZ is an important prerequisite for improving the transparency of financial statements to the public. Good accountability media can take the form of a report in which expresses the achievement of goals through organizational 
resource management, as the achievement of goals is one of the measurements of individual and organizational performance (Baharuddin, 2015). As an accountable LAZ to the public, the accountability of the financial statements is actualized by presenting the LAZ financial statements which are considered to be unqualified.

In relation to the accountability, establishment of inspection mechanisms is essential in order to ensure that agent's work is credible and accountable. The result of research of Language and Culture Center (LCC) of State Islamic University (UIN) Syarif Hidayatullah Jakarta (2005), shows that $94 \%$ of BAZIS holds financial statement, all (100\%)of LAZIS holds financial statement. While for ZIS of Mosque about $97 \%$ hold financial statement. For internal supervision, $93 \%$ of LAZIS and only $65 \%$ of ZIS Mosques has the internal supervision. Furthermore, for external supervision, predominantly BAZIS has $54 \%$.

In general, LAZ accounting principles must meet general accounting standards, namely: accountability, auditable, simplicity (Hermawan, Sigit \& Artriana, Gianti 2010). Accountability means that bookkeeping must be justified because it must be supported by valid and authoritative evidences. Auditable means that bookkeeping can be easily understood by the users of financial statements, easy to trace and can be matched. Simplicity means that bookkeeping is adapted to simple practicality and can be adapted to the needs of LAZ without changing the principle of financial statements preparation. The components of the financial statements according to PSAK 109 consist of: Balance Sheet (Statement of Financial Position), Statement of Fund Changes, Statement of
Asset Changes Under Management, Cash Flow Statement, and Notes to Financial Statements.

The Statement of Financial Position (Balance Sheet) of LAZ according to PSAK 109 , presents accounts with classification of current assets, non-current assets, shortterm liabilities, long-term liabilities, and Fund Balance. The Fund Balance is presented separately between zakat fund, infaq / alms fund, amil fund, and non-halal fund.

\section{Acceptance of Zakat Infaq Shodaqoh Fund}

Acceptance is the receipt of Zakat, Infaq or Shodaqoh from muzakki, either in the form of money or goods received by the fund receiving committee. The acceptance of the zakat payment starts from a muzakki who is about to pay his zakat, then the receiving committee transfer it into the zakat receipt form. While the acceptance of funds based on its characteristics according to Accounting Guidelines of Zakat Management Organization 2009 (PA OPZ: 2009) can be grouped into two. First, acceptance of fund by sources. Second, acceptance by programs.

LAZ collects zakat infaq shodaqoh from donors via bank transfer and cash deposit. Bank transfer is a method where the donors do not have to come to the counter, but only via bank transfer or ATM. While the cash method is a donor donating ZIS comes directly to the office. Acceptance of Zakat is recognized when cash or non-cash assets are received. Zakat received from the donor is recorded as an addition to zakat fund as much as: the amount received, if in cash, and fair value (market price, if market price is not available, it may use other fair value determination methods in accordance with

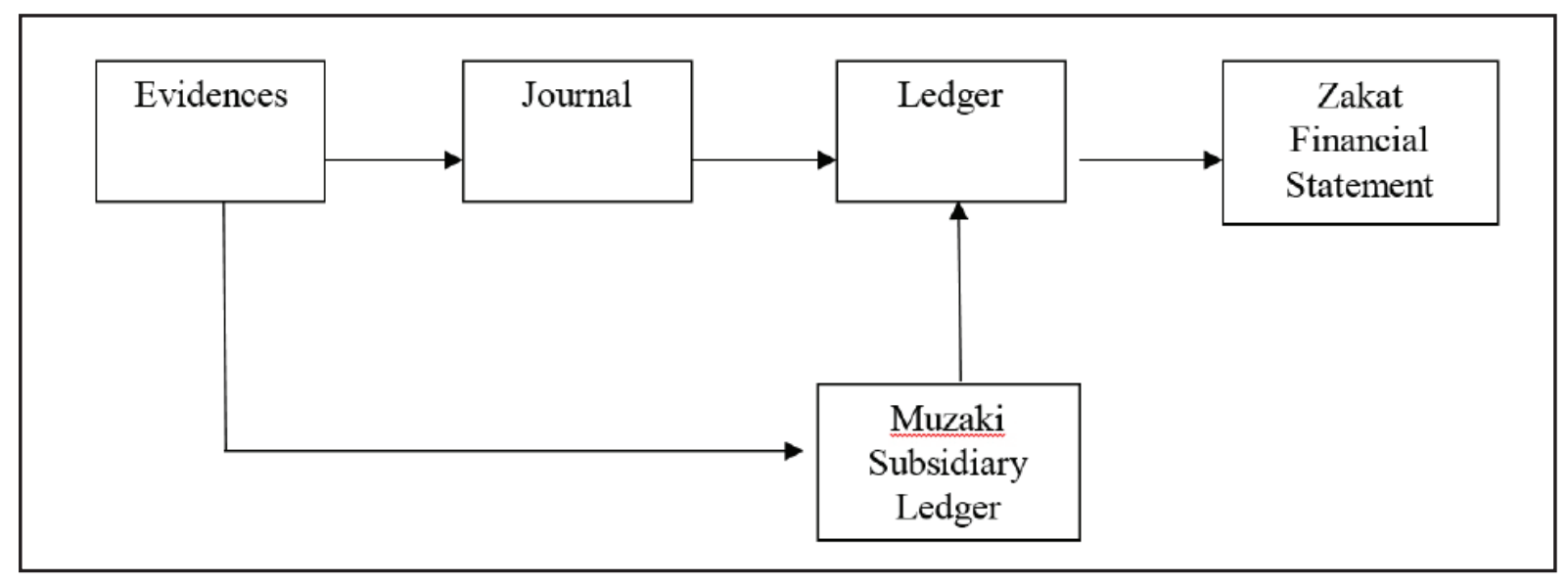

Figure 1. Presentation Procedure of Zakat Financial Statement 
the relevant Financial Accounting Standard (PSAK 109, IAI 2011).

A study of Sugiyo et al (2009) states that the potential of ZIS in Central Java amounted to $\operatorname{Rp} 4,017,638,091,692$. The potential of ZIS and mapping in Semarang City is Rp $153,445,980,564$. The amount of ZIS collected is Rp 4,082,637,195 for Central Java where it spreads in Semarang City as

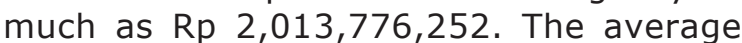
absorption rate of ZIS by LAZ in Central Java is yet low, i.e. only 0.1 percent. Based on this research, it shows that there are still many sources of zakat which has not been worked on.

\section{Research Methodology}

The population of this research is nonstate zakat agencies in Semarang City, Central Java Province. The sample was taken by using purposive sampling, which is the zakat management organization in Semarang City which has the largest source of acceptance of zakat and the widest distribution. Samples of research taken include: BAZNAS Semarang City, LAZISBA Baiturrahman Mosque, DPU Daarut Tauhid (DT Public Works Services), Rumah Zakat, PKPU, and Dompet Dhuafa. BAZNAS Semarang City is a Zakat Collection Agency established by the government. LAZISBA is a zakat agency managed by the mosque boards. Dompet Dhuafa is the oldest LAZ and mass-media based, while the others, PKPU and Rumah Zakat are LAZ managed by private foundations.

This research applied both primary and secondary data. The primary data were obtained by delivering the questionnaire directly to find out the operational activities of LAZ. The questionnaire was conducted to obtain data on the level of acceptance zakat, the quality of accounting information, accountability, transparency, financial statements. Primary data were obtained in depth through observation, documentation and questionnaires. The research team conducted an observation (field survey) to the object of research by conducting interviews directly to the parties involved in zakat management. The questionnaire addressed to the payer of zakat (muzakki) who became the donors of LAZ in question. As many as 100 envelopes containing questionnaires were proportionally distributed at selected non-state zakat agencies (LAZ). The question items were adapted from Nurhayati, Nunung et al.'s research (2014).
The secondary data were obtained in the form of financial statements, publications and SOPs. Furthermore, these data were classified in accordance with the subject of the research. Data collection was conducted in the first two months of 2016. Before the data processing was conducted, the level of validity and reliability of the research instruments would be tested first. After the data was collected then the next step was to process the data and analyze the research data. Causal relationships analysis (causality) among the variables which present in the paradigm of research is implemented by using multiple regression analysis. Research variables and measurement methods can be seen in Table 1.

Table 1

Research Variables

\begin{tabular}{|c|c|c|}
\hline Variable & $\begin{array}{l}\text { Sub } \\
\text { Variable }\end{array}$ & Measurement \\
\hline $\begin{array}{l}\text { 1. Quality of } \\
\text { Accounting } \\
\text { Information }\end{array}$ & $\begin{array}{l}\text { a. Accurate } \\
\text { b. Relevant } \\
\text { c. Punctual } \\
\text { d. Complete }\end{array}$ & $\begin{array}{l}\text { Multiple } \\
\text { Regression } \\
\text { Analysis }\end{array}$ \\
\hline 2. Accountability & $\begin{array}{l}\text { a. Notice } \\
\text { Board } \\
\text { b. Letters/ } \\
\text { Direct } \\
\text { Reports } \\
\text { to Muzaki } \\
\text { c. Regular } \\
\text { Bulletin } \\
\text { d. Newspa- } \\
\text { per } \\
\text { e. Email/ } \\
\text { internet } \\
\text { f. Brochure }\end{array}$ & $\begin{array}{l}\text { Multiple } \\
\text { Regression } \\
\text { Analysis }\end{array}$ \\
\hline 3. Transparency & $\begin{array}{l}\text { a. Open } \\
\text { b. Easy } \\
\text { c. Accessible }\end{array}$ & $\begin{array}{l}\text { Multiple } \\
\text { Regression } \\
\text { Analysis }\end{array}$ \\
\hline $\begin{array}{l}\text { 4. level of } \\
\text { Acceptance of } \\
\text { Zakat Fund }\end{array}$ & $\begin{array}{l}\text { a. Accep- } \\
\text { tance of } \\
\text { fund by } \\
\text { sources } \\
\text { b. Accep- } \\
\text { tance of } \\
\text { fund by } \\
\text { programs }\end{array}$ & $\begin{array}{l}\text { Multiple } \\
\text { Regression } \\
\text { Analysis }\end{array}$ \\
\hline
\end{tabular}

The Research Framework is illustrated in the following research model (figure 2). $\mathrm{H} 1$ proves that "Quality of the Information significantly influences the acceptance of zakat fund at LAZ Semarang City." H2 proves that "Accountability significantly influences the acceptance of zakat fund at LAZ Semarang City." H3 proves that "Transparency significantly influences the acceptance of zakat fund at LAZ Semarang 


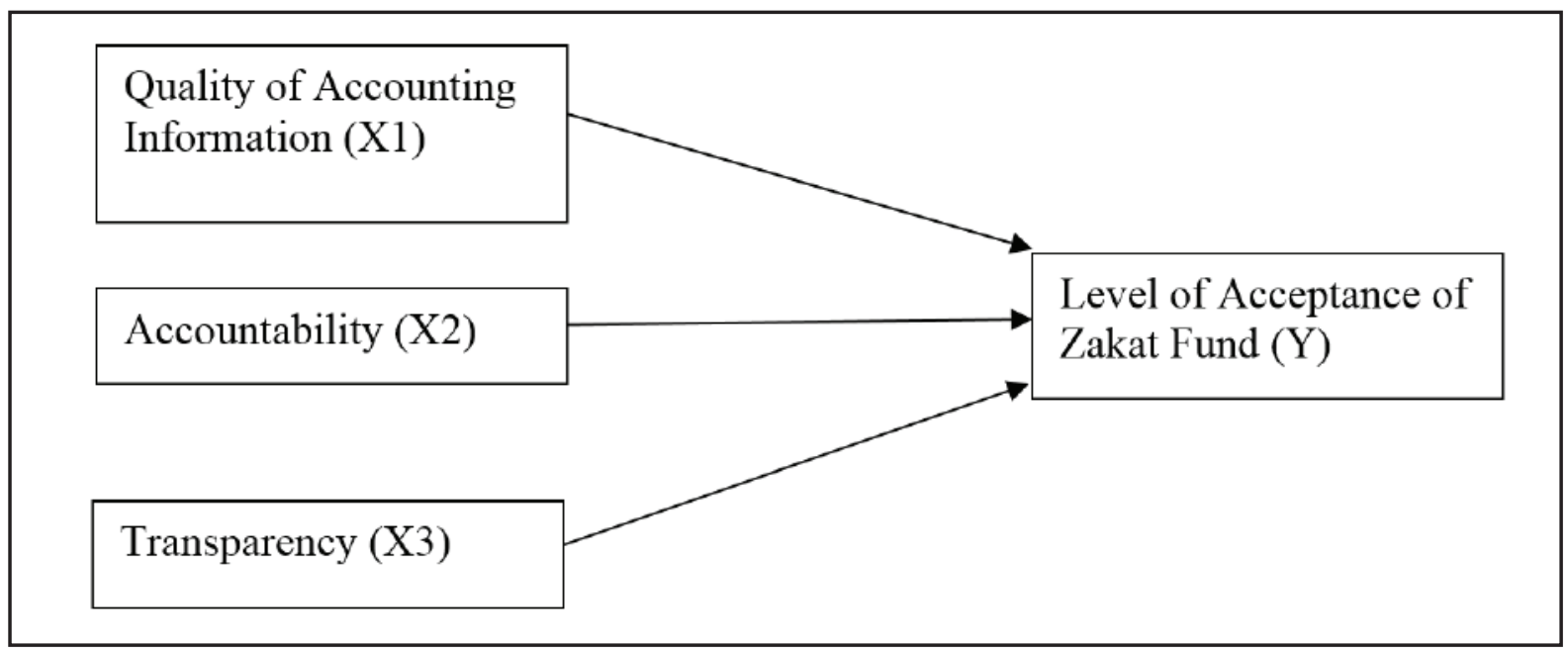

Figure 2. Research Framework

City."

\section{Results and Discussion}

To collect the data, questionnaires were distributed to as many as LAZ in Semarang City, either for the organizers or the donors in the first place. The questionnaires were sent to the selected LAZ started in June 2016 and awaited their return until the end of July 2016. The questionnaire distributed is as follows in Table 2.

Table 2

\section{Distribution of the Sent Questionnaire}

\begin{tabular}{llll}
\hline No. & Name of LAZ/ BAZ & Sent & Returned \\
\hline 1 & BAZNAS Semarang City & 10 & 6 \\
2 & PKPU & 10 & 10 \\
3 & DPU Daarut Tauhiid & 10 & 8 \\
4 & Lazis Baiturrahman & 20 & 10 \\
5 & Rumah Zakat & 20 & 20 \\
6 & Dompet Dhuafa & 20 & 20 \\
& Total & 90 & 74 \\
\hline
\end{tabular}

Source: Processed data, 2016

A difference in the number of questionnaires sent is because several LAZ disapproves questionnaires to be sent to the donors. LAZ which are willing to be surveyed along with the donors are LAZISBA, Rumah Zakat, and Dompet Dhuafa, the rest are resisting for privacy reasons of each donor. By looking at the response rate of return of the questionnaires of $82 \%$, it means that the data is acceptable to investigate. Characteristics of the respondents include sex, age, education, marital status, position in $\mathrm{LAZ}$, reciting $\mathrm{Al}-$ Qur'an from the organizer, length of work of the organizer and organizer position within the company.
Table 3

Respondent Characteristics

\begin{tabular}{|c|c|c|}
\hline Characteristics & Frequency & $\%$ \\
\hline \multicolumn{3}{|l|}{ Sex } \\
\hline Male & 34 & 45,9 \\
\hline Female & 40 & 54,1 \\
\hline \multicolumn{3}{|l|}{ Age } \\
\hline$<21$ years old & 9 & 12,2 \\
\hline $21-30$ years old & 34 & 45,9 \\
\hline $31-40$ years old & 20 & 27,0 \\
\hline $41-50$ years old & 10 & 13,5 \\
\hline \multicolumn{2}{|l|}{ Education } & 1,4 \\
\hline $\begin{array}{l}\text { High School degree and } \\
\text { equivalent }\end{array}$ & 13 & 17,6 \\
\hline D3 & 11 & 14,9 \\
\hline Bachelor degree & 42 & 56,8 \\
\hline Master degree & 7 & 9,5 \\
\hline Doctoral degree & 1 & 1,4 \\
\hline \multicolumn{3}{|l|}{ Marital Status } \\
\hline Married & 45 & 60,8 \\
\hline Single & 29 & 39,2 \\
\hline \multicolumn{3}{|l|}{ Position in LAZ } \\
\hline Organizer & 41 & 55,4 \\
\hline Donor & 33 & 44,6 \\
\hline \multicolumn{3}{|l|}{ Reciting Koran } \\
\hline Able & 41 & 55,4 \\
\hline Not filling & 33 & 44,6 \\
\hline \multicolumn{3}{|l|}{ Length/ Work Period } \\
\hline 0-1 year & 17 & 23,0 \\
\hline 2-3 years & 14 & 18,9 \\
\hline 4-5 years & 2 & 2,7 \\
\hline$>5$ years & 8 & 10,8 \\
\hline No Answer & 33 & 44,6 \\
\hline \multicolumn{3}{|l|}{ Position in Company } \\
\hline Leader & 7 & 9,5 \\
\hline
\end{tabular}




\begin{tabular}{lll} 
Not Leader & 34 & 45,9 \\
No Answer & 33 & 55,9 \\
\hline
\end{tabular}

Based on Table 3 above, it is known that most of the respondents are male, 2130 years old, undergraduate, married, their position as managers, from all managers all can read Alquran, have new working period ( $0-1$ year) and most of them are not corporate leaders. The following shows how the responses of respondents regarding the level of acceptance of zakat fund, the quality of accounting information, accountability, and transparency, presented in the table showing the mean, minimum, maximum value and standard deviation. Below is a table 4 about descriptive statistics on the question of Level of Acceptance of Zakat Fund's variables.

Table 4

Respondents Answer Score by Level of Acceptance of Zakat Fund Variables

\begin{tabular}{|c|c|c|c|c|c|}
\hline & $\mathrm{N}$ & $\begin{array}{l}\text { Mini- } \\
\text { mum }\end{array}$ & $\begin{array}{l}\text { Maxi- } \\
\text { mum }\end{array}$ & Mean & $\begin{array}{l}\text { Std. } \\
\text { De- } \\
\text { via- } \\
\text { tion }\end{array}$ \\
\hline $\begin{array}{l}\text { Level of } \\
\text { Acceptance of } \\
\text { Zakat Fund }\end{array}$ & 74 & 4 & 5 & 4.27 & .442 \\
\hline $\begin{array}{l}\text { Quality of } \\
\text { Accounting } \\
\text { Information }\end{array}$ & 74 & 3 & 5 & 4.26 & .577 \\
\hline Accountability & 74 & 2 & 5 & 4.34 & .480 \\
\hline Transparency & 74 & 3 & 5 & 4.40 & .431 \\
\hline $\begin{array}{l}\text { Valid N } \\
\text { (listwise) }\end{array}$ & 74 & & & & \\
\hline
\end{tabular}

Based on Table 4 the average rate of acceptance of zakat fund is 4.27 nearly the score 4 . The average score of 4.27 gives the meaning that the responses of the respondents to the acceptance of zakat fund fall in the high category. The average score of 4.26 gives meaning that the responses of respondents to the quality of accounting information fall in the high category. The average score of 4.34 gives meaning that the responses of respondent to the accountability fall in the high category. The average score of 4.40 gives meaning that the responses of respondent to transparency fall in the high category. The highest average score of 4.40 achieved by transparency variable indicates that among the four variables under study, transparency is perceived as the highest variable by respondents.

Instrument test aims at determining the quality of measuring instruments including validity and reliability test. The instrument test is conducted by using research questionnaire consisting of 22 point of statements. With the details of 5 question items about the Quality of Accounting Information variable (X1), 5 items about the Accountability variable (X2), 6 items about Transparency variable (X3) and 6 items about the Level of Acceptance of Zakat Fund variables $(Y)$. Questionnaire obtained from 74 respondents who are being the samples of the study. Then the validity and reliability is tested with the assistance of a computer program, SPSS version 15.

Validity test is used to determine the feasibility of question items in defining a variable (Ghozali, 2007). The question item is said to be valid if it has $r$ count (item-total correlation) higher than $r$ table. The value of $r$ table is obtained from the value of $r$ product moment pearson one side with $\mathrm{df}=\mathrm{n}-2$. So $\mathrm{df}=74-2=72$, then $r$ table $=0.1927$. The results of the validity test of each question item can be seen in Table 5 .

\section{Table 5}

\section{The Results of validity test}

\begin{tabular}{llll}
\hline Variable & $\begin{array}{l}\text { Ques- } \\
\text { tion } \\
\text { Item }\end{array}$ & $\begin{array}{l}\text { rcount } \\
\text { Range }\end{array}$ & $\begin{array}{l}\text { De- } \\
\text { scrip- } \\
\text { tion }\end{array}$ \\
\hline $\begin{array}{l}\text { Quality of } \\
\begin{array}{l}\text { Accounting } \\
\text { Information }\end{array}\end{array}$ & 5 & $0,651-0,836$ & Valid \\
$\begin{array}{l}\text { Accountability } \\
\begin{array}{l}\text { Transparency } \\
\text { Acceptance Rate }\end{array}\end{array}$ & 6 & $0,325-0,724$ & Valid \\
of Zakat Fund & 6 & $0,494-0,729$ Valid \\
\hline
\end{tabular}

Source: Processed primary data, 2016

Based on Table 5, all variables in this study have a minimum $r$ value of 0.325 in Accountability variable and maximum $r$ value of 0.729 . The minimum $r$ value is still higher than $r$ table, so all the question items on the research variable are valid and can be used for the research.

Reliability test is addressed to measure the stability and consistency of respondents in answering the question items which are the dimensions of a variable and arranged in a form of questionnaire (Ghozali, 2007). Reliability test is performed on instruments that have been declared valid in the validity test while on the invalid/ drop statements, reliability test is not performed. Reliability test is performed using SPSS version 15 with Alpha Cronbach test. If the value of a of the 
variable under study is higher than $r$ table $(0.1726)$, then it is said that the variable is reliable (Santoso, 2000). The results of reliability test of all studied variables can be seen in Table 6.

Table 6

The Results of Reliability Test

\begin{tabular}{|l|l|l|l|}
\hline Variable & $\begin{array}{l}\text { Ques- } \\
\text { tion } \\
\text { Item }\end{array}$ & $\begin{array}{l}\text { Cron- } \\
\text { bach's } \\
\text { Alpha }\end{array}$ & $\begin{array}{l}\text { De- } \\
\text { scrip- } \\
\text { tion }\end{array}$ \\
\hline $\begin{array}{l}\text { Quality of Accounting } \\
\text { Information }\end{array}$ & 5 & 0,881 & Reliable \\
\hline Accountability & 5 & 0,765 & Reliable \\
\hline Transparency & 6 & 0,823 & Reliable \\
\hline $\begin{array}{l}\text { Acceptance Rate of } \\
\text { Zakat Fund }\end{array}$ & 6 & 0,685 & Reliable \\
\hline
\end{tabular}

Source: Processed primary data, 2016

From table 6 it is known that the value of cronbach's alpha (a) of the three variables under study is above 0.6. Therefore, it can be concluded that the variables used in this study meet the required level of reliability.

Normality test used in this research is One Sample Kolmogorov-Smirnov Test equipped with observation by means of histogram. In One Sample KolmogorovSmirnov test, if a residual has Asymp. Sig (2-tailed) below the 0.05 significance level (probability $<0.05$ ) it means that those variables have abnormal distribution and vice versa.
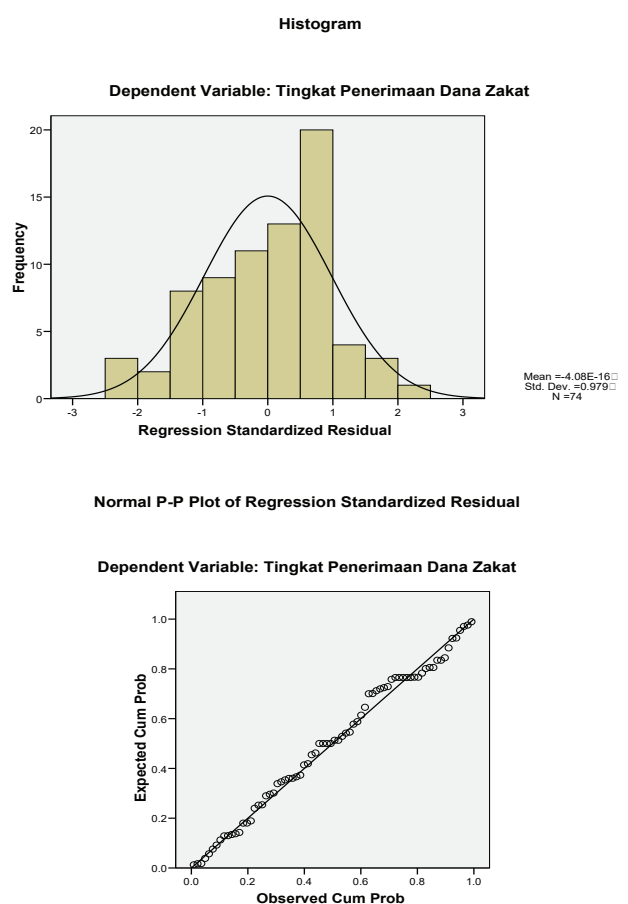

Figure 3. Normality Test Chart

Based on the histogram, it shows that the rod shows are exactly in the middle, so it can be said the data is normally distributed and from the next figure, the dots are around the diagonal line, it can be said that the data is normally distributed. Normality test results are more valid using Kolmogorov Smirnov test, as presented in Table 7.

Table 7

Normality Test

One-sample Kolmogorov-Smirnov Test

\begin{tabular}{|c|c|}
\hline & $\begin{array}{l}\text { Unstandardized } \\
\text { Residual }\end{array}$ \\
\hline $\mathrm{N}$ & 74 \\
\hline Normal Parameters a.b Mean & .0000000 \\
\hline Deviation $\quad$ Std. & 1.58380010 \\
\hline $\begin{array}{l}\text { Most Extreme } \\
\text { Absolute }\end{array}$ & .082 \\
\hline Differences & $\begin{array}{r}.056 \\
-.082\end{array}$ \\
\hline Negative & \\
\hline Kolmogorov-Smirnov Z & .708 \\
\hline Asymp. Sig (2-tailed) & .698 \\
\hline
\end{tabular}

From the statistical test results the value of Asymp. Sig obtained above 0.05 is 0.698 . The sig value higher than $5 \%$ indicates that this assessment reinforces the results obtained from the chart therefore it is proven that the data is normally distributed.

Multicollinearity test aims to determine whether in the regression model the existence of correlation between independent variables is found. A good regression model should not be correlated between independent variables. To detect the presence or absence of multicollinearity in the regression, it can be seen from: (1) tolerance value, (2) the value of variance inflation factor (VIF). The multicollinearity free regression model has a tolerance value above 0.1 or VIF below 10 (Ghozali, 2007). If the tolerance value is below 0.1 or VIF above 10 then there is multicollinearity. The multicollinearity test results can be seen in Table 8 .

Table 8 Multicollinearity Test Coefficients

\begin{tabular}{llll}
\hline \multirow{2}{*}{ Model } & \multicolumn{2}{c}{ Collinearity Statistics } \\
\cline { 3 - 4 } & Tolerance & VIF \\
\hline $1 \quad$ Quality of Accounting & .444 & 2.252 \\
Information & .361 & 2.768 \\
& Accountability & .388 & 2.578 \\
\hline
\end{tabular}


a. Dependent Variable: Level of Acceptance of Zakat Fund

According to Table 8 , the Tolerance values ranged from 0.252 to 2.768 and VIF values ranged from 0.361 to 0.444 . The smallest Tolerance value is higher than 0.1 and the highest VIF value 2.768 is yet smaller than 10 . So it can be concluded that the regression model does not contain multicollinearity thus the analysis can be continued.

The autocorrelation test aims to determine whether the regression model has a correlation between the disturbance error in $t$ period and the disturbance error in the previous period ( $t-1)$. If there is a correlation, it is called as an autocorrelation problem. There are several ways to detect symptoms of autocorrelation, in this study the Run test is performed. According to Ghozali (2013) a model is free from autocorrelation problems when the value of Sig. is higher than 0,05.

\section{Table 9}

Autocorrelation test Run Test

\begin{tabular}{lc}
\hline & $\begin{array}{c}\text { Unstandardized } \\
\text { Residual }\end{array}$ \\
\hline Test Value & .02703 \\
Cases < Test Value & 37 \\
Cases $>=$ Test Value & 37 \\
Total Cases & 74 \\
Number of Runs & 30 \\
Z & 1.873 \\
Asymp. Sig. (2-tailed) & .061 \\
\hline
\end{tabular}

a. Median

Based on Table 9 the autocorrelation test using Run Test, a value of 0.061 , higher than 0.05 is obtained, so it can be concluded that the model does not contain autocorrelation problems.
The heteroscedasticity test aims to test whether in the regression model there is a variance inequality of the residual from one observation to another observation. If the variance of the residual from one observation to another observation is constant, it is called as homoscedasticity and if different it is called heteroscedasticity (Ghozali, 2007). The way to detect the presence or absence of heteroscedasticity is by using glejser test. The glejser test is to regress the independent variable to the value of Absolute Residual model. If independent variables are statistically significant, then there is indication of heteroscedasticity. Before performing glejser test, test the heteroscedasticity in form of chart first. Heteroscedasticity test results as follows in figure 4.

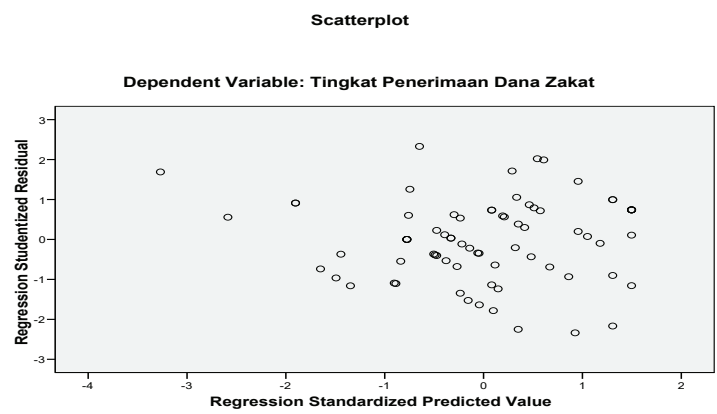

Figure 4. Heteroscedasticity Test Chart

According to the scatter plot chart it can be seen that the dots is spreading and do not form the lines and corrugated pattern or other certain patterns, so it can be said that it is free from heteroscedasticity problem. This is proven by statistical test in table 10 .

Based on Table 10 of the glejser test results, the $t$ value is not statistically significant, meaning that the sig value obtained is not smaller than 0.05 . So it can be concluded that the model does not contain heteroscedasticity problem. Multiple

Table 10

Heteroscedasticity Test Glejser Test Method Coefficients ${ }^{a}$

\begin{tabular}{|c|c|c|c|c|c|}
\hline \multirow[t]{2}{*}{ Model } & \multicolumn{2}{|c|}{$\begin{array}{l}\text { Unstandardized } \\
\text { Coefficients }\end{array}$} & \multirow{2}{*}{$\begin{array}{l}\text { Standardized } \\
\text { Coefficients } \\
\text { Beta } \\
\end{array}$} & \multirow[t]{2}{*}{$\mathrm{T}$} & \multirow[t]{2}{*}{ Sig. } \\
\hline & $\mathrm{B}$ & Std. Error & & & \\
\hline $1 \quad$ (Constant) & 1.047 & 1.124 & & .931 & .355 \\
\hline $\begin{array}{l}\text { Acceptance Rate of Zakat } \\
\text { Fund }\end{array}$ & -.027 & .068 & -.076 & -.400 & .690 \\
\hline $\begin{array}{l}\text { Quality of Accounting } \\
\text { Information }\end{array}$ & .091 & .059 & .277 & 1.546 & .126 \\
\hline Accountability & -.047 & .076 & -.120 & -.621 & .537 \\
\hline
\end{tabular}


Table 11

t Test

\begin{tabular}{|c|c|c|c|c|c|c|c|}
\hline \multirow[b]{2}{*}{ Model } & \multicolumn{2}{|c|}{$\begin{array}{l}\text { Unstandardized } \\
\text { Coefficients }\end{array}$} & \multicolumn{2}{|l|}{$\begin{array}{l}\text { Standardized } \\
\text { Coefficients }\end{array}$} & \multirow[b]{2}{*}{ Sig. } & \multicolumn{2}{|c|}{ Collinearity Statistics } \\
\hline & $\mathrm{B}$ & $\begin{array}{l}S \mathrm{t} \mathrm{d} \\
\text { Error }\end{array}$ & Beta & $\mathrm{t}$ & & Tolerance & VIF \\
\hline $\begin{array}{ll}1 & \text { (Constant) }\end{array}$ & 4.680 & 1.982 & & 2.362 & .021 & & \\
\hline $\begin{array}{l}\text { Quality of Accounting } \\
\text { Information }\end{array}$ & .238 & .098 & .257 & 2.398 & .019 & .444 & 2.252 \\
\hline Accountability & .404 & .131 & .366 & 3.082 & .003 & .361 & 2.768 \\
\hline Transparency & .271 & .118 & .265 & 2.307 & .024 & .388 & 2.578 \\
\hline
\end{tabular}

Dependent Variable: Level of Acceptance of Zakat Fund Source: Processed primary data, 2016

linear regression tests aim to determine the effect of Quality of Accounting Information, Accountability, Transparency on the Level of Acceptance of Zakat Fund. Multiple linear regression tests include $\mathrm{F}$ test, $\mathrm{t}$ test and Determination Coefficient test.

t test aims to observe the partial influence of Quality of Accounting Information, Accountability, Transparency on the Level of Acceptance of Zakat Fund, the full results can be seen on Table 11.

Based on Table 11, regression coefficient of each independent variable is obtained: Quality of Accounting Information, Accountability, Transparency on Level of Acceptance of Zakat Fund marked by each coefficient which is positive. From the results of multiple linear regression statistic tests, a regression equation is drawn as follows: $Y=$ $0.257 \mathrm{X} 1+0.366 \mathrm{X} 2+0.265 \mathrm{X} 3$

The regression coefficient of Quality of Accounting Information variable (X1) is 0,257 , it means that if other independent variable is considered as constant, then the improvement Quality of Accounting Information variable of 1 unit is followed by the increase of Level of Acceptance of Zakat Fund equal to 0,257 points. While the regression coefficient of Accountability variable (X2) is 0.366 , meaning that if another independent variable is considered as constant then the increase in Accountability of 1 unit is followed by an increase of Level of Acceptance of Zakat Fund of 0.366 points. Furthermore, the regression coefficient of Transparency variable (X5) is 0,265 , it means that if other independent variable is considered constant, Transparency increase of 1 unit is followed by Level of Acceptance of Zakat Fund increase of 0,265 points.

$\mathrm{F}$ test aims to see the simultaneously effect of: Quality of Accounting Information, Accountability, Transparency on Level of Acceptance of Zakat Fund, the full results can be seen in Table 12.

Table 12 ANOVA Test ANOVA A $^{b}$

\begin{tabular}{|c|c|c|c|c|c|}
\hline Model & $\begin{array}{l}\text { Sum of } \\
\text { Squares }\end{array}$ & $\mathrm{df}$ & $\begin{array}{l}\text { Mean } \\
\text { Square }\end{array}$ & $\mathrm{F}$ & Sig. \\
\hline $\begin{array}{ll}1 & \begin{array}{l}\text { Re- } \\
\text { gres- } \\
\text { sion }\end{array}\end{array}$ & 329.750 & 3 & 109.917 & 42.018 & $.000^{\mathrm{a}}$ \\
\hline Residual & 183.115 & 70 & 2.616 & & \\
\hline Total & 512.865 & 73 & & & \\
\hline
\end{tabular}

a. Predictors: (Constant), Transparency, Quality of Accounting Information, Accountability

b. Dependent Variable: Level of Acceptance of Zakat Fund

Source: Processed primary data, 2016

Based on Table 12, Anova Test or $F$ test resulted the value of $F$ count is 42,018 higher than $\mathrm{F}$ table ( $\mathrm{F}$ table value with $\mathrm{df} 1=3$ and df $2=70$ that is 2,7355 ) with significance level of 0,000 . The probability of significance is far less than 0.05 , so the regression model can be used to predict the Level of Acceptance of Zakat Fund.

Determination coefficient test aims to observe how much the Quality of Accounting Information, Accountability, Transparency in explaining the Level of Acceptance of Zakat Fund, for the full results see Table 13.

Based on Table 13, it is known that the value of Adjusted R Squared is 0,628 , it means that the variation of Level of Acceptance of Zakat Fund can be explained by the three independent variables by $62,8 \%$, while the rest $(100 \%-62,8 \%=37,2 \%)$ are explained by other causes outside the study. The answer to the hypothesis test is based on the statistical test of $t$ value in Table 12 . 
MIMBAR, Vol. 33, No. $1^{\text {st }}$ (June, 2017), pp. 62-73

Table 13

Determination Coefficient (Summaryb Model)

\begin{tabular}{|c|c|c|c|c|c|}
\hline Model & $\mathrm{R}$ & R Square & $\begin{array}{l}\text { Adjusted } \\
\text { Square }\end{array}$ & $\begin{array}{l}\mathrm{R} \text { Std. Error of the } \\
\text { Estimate }\end{array}$ & Durbin-Watson \\
\hline 1 & $.802^{a}$ & .643 & .628 & 1.617 & 1.646 \\
\hline
\end{tabular}

The first hypothesis states that the Quality of Accounting Information affects the Level of Zakah Fund Receipts. The statistical test results obtained sig value. of 0.019 smaller than 0.05 , and t count of 2.398 higher than $t$ table $( \pm 1.9944)$. The value of $t$ count is positive and significant, meaning $\mathrm{Ho}$ is rejected, and $\mathrm{Ha}$ is accepted, there is a positive and significant influence of Quality of Accounting Information variable on Level of Acceptance of Zakat Fund. So the first hypothesis which states that the Quality Accounting Information has a positive effect on Level of Acceptance of Zakat Fund is accepted. The average value of the quality of accounting information variable of 4.26 gives meaning that the response of respondents about the quality of accounting information is in the high category. The results of this study are similar to the research of Nurhayati, Nunung et al (2014), who find that the quality of accounting information has a positive and significant influence both simultaneously and partially on the level of acceptance of zakat.

The second hypothesis states that Accountability affects the Level of Acceptance of Zakat Fund. The statistical test results obtained sig value. of 0.003 smaller than 0.05 , and $t$ count of 3.082 higher than t table $( \pm 1.9944)$. The value of $t$ count is positive and significant, meaning that $\mathrm{Ho}$ is rejected, and $\mathrm{Ha}$ is accepted, there is a positive and significant influence of Accountability variable on Level of Acceptance of Zakat Fund. So the second hypothesis which states that Accountability affects the Level of Acceptance of Zakat Fund is accepted. An average score of 4.34 gives meaning that respondent' responses about accountability is in the high category. The results of this study are in accordance with the findings of Nurhayati, Nunung et al (2014) that Accountability has a positive and significant influence both simultaneously and partially on the level of acceptance of zakat.

The third hypothesis states that
Transparency affects the Level of Acceptance of Zakat Fund. The statistical test results obtained sig value. of 0.024 smaller than 0.05 , and $t$ count of 2.307 higher than $t$ table $( \pm 1.9944)$. The value of $t$ count is positive and significant, meaning $\mathrm{Ho}$ is rejected, and $\mathrm{Ha}$ accepted, there is a positive and significant influence of Transparency variable on the Level of Acceptance of Zakat Fund. So the third hypothesis that states Transparency affects the Zakah acceptance rate is accepted. The average score of 4.40 gives meaning that respondent' responses to transparency are in the high category. The highest average score of 4.40 achieved by transparency variable indicates that among the four variables under study, transparency is perceived as the highest by respondents. The result of this research is the similar to Nurhayati, Nunung et al (2014), which states that Transparency has positive and significant influence both simultaneously or partially on level of acceptance of zakat.

Acceptance of Zakat are recognized when cash or non-cash assets are received. Zakat received from the donor is recorded as an addition of zakat fund as much as: the amount received, if in cash, and fair value (market price, if market price is unavailable, it may use other fair value determination method in accordance with relevant Financial Accounting Standard/ SAK. If there is a decrease of Non-cash asset of zakat, then the amount of the loss is treated as a deduction of amil funds depending on the cause of the loss. Decrease in the value of zakat assets (IAI, 2010 ) is recognized as (a) zakat reductions, if not caused by negligence of amil; (b) loss and reduction of amil funds, if caused by negligence of amil.

Infaq or alms received is acknowledged as addition of restricted or unrestricted infaq / alms funds in accordance with the purpose of infaq / alms giving to the amount received. Infaq / alms received can be cash or noncash assets. Non-cash assets can be current 
assets or non-current assets. Non-current assets received are measured at fair value on receipt and recognized as non-current assets of infaq / alms.

Zakat which is distributed to the eight recipients, including amil is acknowledged as a reduction of zakat fund in the amount given. In accordance with the rules of sharia, amil have a right to take some parts of zakat to cover the operational costs in managing the Zakat Collection Agency/LAZ. The amount of zakat distributed to the zakat recipients is determined by amil in accordance with the principles of sharia, reasonableness, ethics, and Zakat Collection Agency prevailing. Distribution of infaq / alms funds is recognized as reduction of infaq / alms funds as much as: (1) amount submitted, if in cash, (2) carrying amount of assets submitted, if in the form of non-cash assets (IAI 2010).

\section{Conclusions}

The study aims at proving empirically the effects of Quality of Accounting Information, Accountability, Transparency on the Level of Acceptance of Zakat Fund, can be drawn some conclusions as follows. Quality of Accounting Information affects the Level of Acceptance of Zakat Fund. Accountability affects the Level of Acceptance of Zakat Fund. Transparency affects the Level of Acceptance of Zakat Fund. The results of this study are strengthen by empirical test of Nurhayati, Nunung et al (2014), which find that the quality of accounting information, accountability, transparency have positive and significant influence both simultaneously or partially on the level of acceptance of zakat.

Recognition of Zakah Fund is recognized when cash / non cash is received. If there is a decrease in the value of the non-cash assets of zakat, the amount of loss borne should be treated as a zakat fund or amil fund reduction depending on the cause of the loss. Recognition of infaq / alms funds is recognized when cash / non cash is received. Non-current asset of infaq / alms donated are recognized at fair value, the depreciation of such assets reduces the infaq / alms fund.

Zakat Collection Agency/ LAZ has not yet fully prepared the financial statements based on Statement of Financial Accounting Standards /PSAK 109. The financial statements that have been prepared including Balance Sheet, Statement of Fund Changes, Cash Flow Statement. Except for the Statement of Asset Changes Under Management and Notes to the Financial Statement is not yet available. As a non-profit sharia institution, LAZ should also be audited by sharia. As an extension of future research on the accountability of LAZ financial statements, the future researchers can develop a research by expanding LAZ objects which have been audited by independent Auditors and Shariah Auditors (Sharia Supervisory Board).

\section{References}

Baharuddin. (2015). Akuntabilitas Pelayanan Publik: Studi Kasus Pelayanan Perijinan Mendirikan Bangunan di Kota Makassar, MIMBAR, Vol 31, No. 2, Desember 2015

Bisri, Zaini AA. (2012). Zakat, Program besar yang terbelangkai. Suara Merdeka No. 32 Th 63, 12 Agustus 2012

Herlina, Lusi. (2004). Pengembangan Transparansi dan Akuntabilitas di KPMM. Jakarta:PIRAC, Ford Foundation dan Tifa.

Hermawan, Sigit \& Astriana, Gianti. (2010), Akuntansi Zakat dan Upaya Peningkatan Transparansi dan Akuntabilitas Lembaga Amil Zakat, Jurnal Ekonomi, Vol 1 No 2, Nopember, Hal 34-42

Huda, Nurul \& Sawarjuwono, Tjiptohadi. (2013). Akuntabilitas Pengelolaan Zakat melalui Pendekatan Modifikasi Action Research. Jurnal Akuntansi Multiparadigma, Vol 4 No 3, Hal 376-388

Ikatan Akuntansi Indonesia. (2011). Pernyataan Standar Akuntansi Keuangan No 109 : Akuntansi Zakat Infak/Sedekah. https://staff.blog.ui.ac.id/martani/ files/2011/04/ED-PSAK-109.pdf. diakses tanggal 16 Februari 2015.

Istutik.(2013). Analisis Implementasi Akuntansi Zakat dan Infak/Sedekah (PSAK 109) pada Lembaga Amil Zakat di Kota Malang, Jurnal Akuntansi Aktual, Vol 2 NO 1 Januari, Hal 19-24

Nikmatuniayah, $\left(2015^{\mathrm{a}}\right)$. Manajemen Strategis Pengelolaan Zakat Lembaga Amil Zakat Infak dan Shodaqoh Baiturrahman (LAZISBA) Semarang, Prosiding Seminar Nasional Terapan Riset Inovatif 2005, Vol 001, Hal 578-595

Nikmatuniayah, Marliyati, (2015 b). Model Akuntabilitas Laporan Keuangan Organisasi Pengelola Zakat di Kota Semarang, MIMBAR, Vol 31, No. 2, Desember 2015

Nurhayati, Nunung dkk. (2014). "Pengaruh Kualitas Informasi Akuntansi, Akuntabilitas dan Transparansi Pelaporan Keuangan terhadap Tingkat Penerimaan Dana Zakat pada Badan Amil Zakat (BAZ) di Jawa Barat". Prosiding SnaPP2014 Sosial, 
Ekonomi, Humaniora, Vol 4, No.1, hlm 577-584.

Sugiyo, Setiawan H.A, Pujiono A. (2009). Model Pemberdayaan Masyarakat miskin binaan Lembaga Amil Zakat Jawa Tengah dalam mengentaskan yang bersumber dari dana zakat infak dan sedekah. Penerbit Universitas Diponegoro.
Suroso. (2007). Manajemen Badan Amil Zakat Infaq dan Shadaqah dalam Upaya Pemberdayaan Ekonomi Islam, Fordema, Vol 7, No 1, Juni, Hal. 99-114.

Wibisono, J. (2011). Rekor Manis PSAK Zakat, Majalah Akuntan Indonesia, No 3 September-Oktober 2011. 